University of Nebraska - Lincoln

DigitalCommons@University of Nebraska - Lincoln

Agronomy \& Horticulture -- Faculty Publications

Agronomy and Horticulture Department

$12-11-2015$

\title{
Soybean Yield and Nodulation Response to Crop History and Inoculation
}

\author{
Stephen Mason \\ University of Nebraska-Lincoln, smason1@unl.edu \\ Tomie Galusha \\ University of Nebraska-Lincoln \\ Zaher Kmail \\ University of Nebraska-Lincoln
}

Follow this and additional works at: https://digitalcommons.unl.edu/agronomyfacpub

Part of the Agricultural Science Commons, Agriculture Commons, Agronomy and Crop Sciences Commons, Botany Commons, Horticulture Commons, Other Plant Sciences Commons, and the Plant Biology Commons

Mason, Stephen; Galusha, Tomie; and Kmail, Zaher, "Soybean Yield and Nodulation Response to Crop History and Inoculation" (2015). Agronomy \& Horticulture -- Faculty Publications. 839.

https://digitalcommons.unl.edu/agronomyfacpub/839

This Article is brought to you for free and open access by the Agronomy and Horticulture Department at DigitalCommons@University of Nebraska - Lincoln. It has been accepted for inclusion in Agronomy \& Horticulture -Faculty Publications by an authorized administrator of DigitalCommons@University of Nebraska - Lincoln. 


\title{
Soybean Yield and Nodulation Response to Crop History and Inoculation
}

\author{
Stephen Mason,* Tomie Galusha, and Zaher Kmail
}

\begin{abstract}
Soybean [Glycine max (L.) Merr.] inoculation was imposed on a long-term continuous grain sorghum [Sorghum bicolor (L.) Moench] and soybean cropping systems study with and without manure application at Mead, NE. The objective was to determine the influence of 28-yr history of continuous grain sorghum and soybean production, inoculation, and manure on soybean yield and nodulation. Average 2 -yr soybean grain yield was $0.5 \mathrm{Mg} \mathrm{ha}^{-1}$ greater on plots with continuous grain sorghum crop history rather than soybean history, even after this history was broken by 2 -yr crop rotation with grain sorghum in the $2 \mathrm{yr}$ previous to the evaluation. Continuous production of soybean in the same field is undesirable, and besides short-term loss of yield from lack of crop rotation, also leads to long-term soybean yield reductions. Manure and inoculation application had no influence on soybean grain yield or number of nodules. Soybean in plots with 28 -yr previous grain sorghum crop history had equal number of nodules to those in plots with soybean crop history and/or Bradyrhizobium japonicum inoculant. It is probable that this lack of response was due to B. japonicum movement among adjacent plots by wind erosion, water erosion, and/or soil transfer from contaminated tillage equipment used to till adjacent plots. Although the basis for long-term soybean crop history on yield is unclear, continuous soybean production should be avoided to prevent soybean yield depression.
\end{abstract}

Published in Agron. J. 108:309-312 (2016)

doi:10.2134/agronj2015.0245

Received 20 May 2015

Accepted 26 Aug. 2015

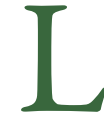

ONG-TERM continuous soybean cropping has received limited study, but is a common production system in Argentina and Brazil (Meriles et al., 2009; SaladoNavarro and Sinclair, 2009). Crop rotation with maize (Zea mays L.) and sorghum have been documented to increase succeeding soybean crop yields by 5 to $16 \%$ (Roder et al., 1989; Peterson and Varvel, 1989).

Soybean and Bradyrhizobium japonicum form a symbiotic relationship to fix atmospheric nitrogen $\left(\mathrm{N}_{2}\right)$ in nodules located on soybean roots. Bradyrhizobium japonicum is not native to soils in the United States, but has been introduced through inoculation of soybean crops and can persist in soils for long periods. Typically soybean yields increase with inoculation in fields with no soybean history (Larson, 2013; Albareda et al., 2009; Schulz and Thelen, 2008; Elkins et al., 1976) or when the soil B. japonicum population is low (Furseth et al., 2012). Larson and Siemann (1998) found that approximately half of the normal population of soybean-compatible rhizobia survived after $30 \mathrm{yr}$ of forage grass production on a field. Similarly, Ruiz Diaz et al. (2009) found only a 3\% yield increase from $B$. japonicum inoculation following 20 plus years of grass pasture. Elkins et al. (1976) found no response to $B$. japonicum inoculation for $11 \mathrm{yr}$ following a well-nodulated soybean crop. Several studies have shown no soybean yield response to inoculation when a well-nodulated soybean crop was produced within 3 to 5 yr (De Bruin et al., 2010; Schulz and Thelen, 2008; Abendroth and Elmore, 2006). However, exceptions exist when nodulation does occur in fields without a soybean crop history (Larson, 2013; van Kessel and Hartley, 2000). Bradyrhizobium japonicum transfer by wind, equipment, and livestock has been suggested, with Lowther and Patrick (1993) reporting that rhizobia can move $4 \mathrm{~m} \mathrm{yr}^{-1}$ downslope.

Manure application increases soil nutrient and organic matter levels, water and nutrient holding capacities, and depending on the soil nutrient status and fertilizer application, can contribute to increased crop yields (Wortman et al., 2012; Kaye et al., 2007). Manure application can indirectly influence soybean nodulation by reducing soybean plant and nodule water stress through increased soil water storage; improving soil oxygen concentration by increasing soil porosity; and contributing $\mathrm{NO}_{3}-\mathrm{N}$ directly or indirectly through mineralization (Kaye et al., 2007; Bagayoko et al., 1992). Manure application has been shown to have both a positive (Ganeshamurthy and Reddy, 2000; Tagoe et al., 2008; Johnson and Hume, 1972) and no effect (Javaid and Mahmood, 2010) on soybean nodule

University of Nebraska, Lincoln, NE 68583. ${ }^{*}$ Corresponding author (smason1@unl.edu). 
numbers and/or quantity of $\mathrm{N}$ fixation depending on soil and climatic conditions.

The objective of this research was to determine the influence of crop history, inoculation, and manure on soybean nodulation and yield.

\section{MATERIAL AND METHODS}

Research was conducted at the University of Nebraska Agricultural Research Development Center near Mead, NE, on a Yutan silty clay loam (fine-silty, mixed, superactive, mesic Mollic Hapludalf) with 2 to $4 \%$ slopes in 2011 and 2012. The experiment was imposed on plots contained in a long-term rotation study established in 1980 (Roder et al., 1988, 1989). The experimental factors studied were crop history, soybean inoculation, and manure application. The crop history was continuous grain sorghum or soybean followed by 2 yr grain sorghum as shown in Table 1 . Plots either received no manure or annual application of fresh beef feedlot manure at $17.3 \mathrm{Mg} \mathrm{ha}^{-1}$ (dry matter) until 2008, applied in spring and incorporated by disking. No manure was applied in 2009 and 2010, but manure was applied to experimental plots at $16.6 \mathrm{Mg} \mathrm{ha}^{-1}$ (dry matter) in 2011 and $12.5 \mathrm{Mg} \mathrm{ha}^{-1}$ (dry matter) in 2012. The manure application goal was 15 to $20 \mathrm{Mg} \mathrm{ha}^{-1}$ (dry matter) each year, but differences in annual manure application rate varied due to differences in water content of the fresh manure. The $\mathrm{N}$ supplied by manure in the 2011 was estimated to be $54 \mathrm{~kg} \mathrm{ha}^{-1}$ in 2011 and $28 \mathrm{~kg} \mathrm{ha}^{-1}$ in 2012 (Wortmann and Shapiro, 2012).

The experiment was conducted in a randomized complete block design with a split-plot treatment arrangement and three replications. The whole plot was a factorial combination of grain sorghum or soybean crop history and with and without manure. Subplots were inoculant treatments with and without
Novozyme Optimize 400 (selected B. japonicum inoculant plus lipochitoligosaccharides) applied on seed immediately before planting at a rate of $0.4 \mu \mathrm{g} \mathrm{seed}^{-1}$. The subplots were $3 \mathrm{~m}$ wide and $7.9 \mathrm{~m}$ long. Weeds were controlled by using herbicides and hand weeding as needed. Due to extreme drought in 2012 (Table 2), supplemental $60 \mathrm{~mm} \mathrm{ha}^{-1}$ irrigation was furrow applied on 23 July to reduce drought stress and approximate average growing conditions.

The soybean variety Asgrow 3332 was planted following disk tillage in both years. Soybean was planted on 30 May 2011 and 3 June 2012 using a six-row John Deere 7100 maxi-merge planter (John Deere, Moline, IL) in $76 \mathrm{~cm}$ row spacing at the rate of 445,000 seeds $\mathrm{ha}^{-1}$.

\section{Soybean Nodule Counts and Grain Yield Determination}

Soils were sampled to depth increments of 0 to 20 and 20 to $60 \mathrm{~cm}$ before planting and analyzed for organic matter, and extractable $\mathrm{P}, \mathrm{K}$, and $\mathrm{Zn}$ using a Mehlich-3 extraction in both years (Combs et al., 1998). Soils were sampled at a depth of 0 to $20 \mathrm{~cm}$ at the V4 (approximately $26 \mathrm{~d}$ after emergence) and R5 soybean stages (approximately $70 \mathrm{~d}$ after emergence) (Pedersen, 2009), and analyzed for $\mathrm{NO}_{3}-\mathrm{N}$ using the automated cadmium reduction method analyzed by flow injection (Gelderman and Beegle, 1998) following calcium phosphate extraction (Combs et al., 1998). Five soybean plants were dug up; carefully washed; and nodules counted at the V4 and R5 growth stages. Grain yield was machine-harvested from the middle two rows of each four-row ( 3 by $9 \mathrm{~m}$ ) plot; machine threshed; weighed; and corrected to $130 \mathrm{~g} \mathrm{~kg}^{-1}$ water content. Subsamples were hand harvested from a $30.5-\mathrm{cm}$ row section before machine harvesting, and then the number of pods (per plant); seeds

Table I. Cropping history between 1980 and $201 \mathrm{II}$ and 2012 at Mead, NE.

\begin{tabular}{|c|c|c|c|c|c|}
\hline \multirow[b]{2}{*}{ Crop history } & \multicolumn{5}{|c|}{ 20II Experiment } \\
\hline & $1980-2008$ & 2009 & 2010 & 2011 & \\
\hline Grain sorghum & Grain sorghum & Grain sorghum & Grain sorghum & $\begin{array}{l}\text { Inoculated or non-inoculated } \\
\text { soybean }\end{array}$ & \\
\hline \multirow[t]{2}{*}{ Soybean } & Soybean & Grain sorghum & Grain sorghum & $\begin{array}{l}\text { Inoculated or non-inoculated } \\
\text { soybean }\end{array}$ & \\
\hline & \multicolumn{5}{|c|}{2012 Experiment } \\
\hline Crop history & $1980-2008$ & 2009 & 2010 & 2011 & 2012 \\
\hline Grain sorghum & Grain sorghum & Grain sorghum & Grain sorghum & Grain sorghum & $\begin{array}{l}\text { Inoculated or non-inoculated } \\
\text { soybean }\end{array}$ \\
\hline Soybean & Soybean & Grain sorghum & Grain sorghum & Grain sorghum & $\begin{array}{l}\text { Inoculated or non-inoculated } \\
\text { soybean }\end{array}$ \\
\hline
\end{tabular}

Table 2. Monthly temperature and precipitation at the Agricultural Research and Development Agronomy Farm, Mead, NE, in 20II and 2012.

\begin{tabular}{|c|c|c|c|c|c|c|c|c|c|}
\hline \multirow[b]{2}{*}{ Month } & \multicolumn{3}{|c|}{ Maximum temperature } & \multicolumn{3}{|c|}{ Minimum temperature } & \multicolumn{3}{|c|}{ Precipitation } \\
\hline & 2011 & 2012 & 30-yr avg. & 2011 & 2012 & 30-yr avg. & 2011 & 2012 & 30-yr avg. \\
\hline & \multicolumn{6}{|c|}{${ }^{\circ} \mathrm{C}$} & \multicolumn{3}{|c|}{$\longrightarrow \mathrm{mm}$} \\
\hline May & 22.5 & 26.5 & 23.1 & 10.6 & 12.0 & 9.7 & 161 & 80 & 75 \\
\hline June & 27.9 & 30.2 & 28.6 & 16.4 & 16.4 & 15.2 & 128 & 93 & 98 \\
\hline July & 31.9 & 35.7 & 30.8 & 20.9 & 19.9 & 17.6 & 73 & 2 & 79 \\
\hline Aug. & 28.8 & 31.9 & 29.5 & 17.3 & 14.5 & 16.2 & 88 & 14 & 96 \\
\hline Sept. & 23.1 & 27.6 & 25.4 & 8.1 & 8.4 & 10.9 & 20 & 34 & 78 \\
\hline Avg./Total & 26.8 & 30.4 & 27.5 & 14.7 & 14.2 & 13.9 & 470 & 223 & 426 \\
\hline
\end{tabular}


per pod; and seed weight were determined (not reported). Seed weights were corrected to $130 \mathrm{~g} \mathrm{~kg}^{-1}$ water content and added back to the grain yield.

\section{Statistical Analysis}

Data were analyzed by using SAS Proc Mixed procedures, version 9.3 (SAS Institute, 2014) for analysis of variance. Crop and manure history, inoculation and year were considered to be fixed effect while replication and interactions with replication were considered to be random. Differences of $P \leq 0.05$ were declared significant.

\section{RESULTS AND DISCUSSION}

\section{Climate}

On average, the maximum and minimum temperatures were below average in 2011 and above average in 2012 (Table 2). In 2011, the average maximum temperature was higher than the 30-yr average only in the month of July, while in 2012 it was consistently 2 to $5^{\circ} \mathrm{C}$ higher than average. Minimum temperatures were higher than average in both years except for the month of August in 2011, and September in both years. Precipitation in 2012 was very low, especially near the critical pod-elongation growth stage (Pedersen, 2009), when low precipitation combined with the high maximum temperatures, resulted in a stressful environment for soybean growth, thus supplemental furrow irrigation of $60 \mathrm{~mm}$ was applied to reduce drought stress and approximate average growing conditions.

\section{Soil Nutrient Levels}

Manure application from 1980 through 2008 increased soil $\mathrm{pH}$ (from 6.7 to 7.0 ); organic matter (from 31 to $33 \mathrm{~g} \mathrm{~kg}^{-1}$ ); $\mathrm{NO}_{3}-\mathrm{N}$ (from 1.9 to $2.9 \mathrm{~g} \mathrm{~kg}^{-1}$ ); $\mathrm{P}$ (from 43 to $165 \mathrm{~g} \mathrm{~kg}^{-1}$ ); $\mathrm{K}$ (from 425 to $634 \mathrm{~g} \mathrm{~kg}^{-1}$ ); and $\mathrm{Zn}$ (from 1.2 to $3.0 \mathrm{~g} \mathrm{~kg}^{-1}$ ) compared to non-manured plots in the top $20 \mathrm{~cm}$. Crop history had no influence on soil organic matter or nutrient levels. Soil levels for all nutrients were well above the sufficiency levels for soybean production in all plots (Ferguson et al., 2006), thus differences in soybean yield would be not be expected based on soil nutrient levels (Wortman et al., 2012; Kaye et al., 2007, Bagayoko et al., 1992).

\section{Grain Yield}

Soybean grain yield differences were caused by crop history. Plots with grain sorghum history yielded $0.5 \mathrm{Mg} \mathrm{ha}^{-1}$ more than those with soybean crop history (Table 3 ). Since all plots were planted to grain sorghum in 2009 and 2010, a similar yield increase of 5 to $16 \%$ would be present for both crop histories (Roder et al., 1089; Peterson and Varvel, 1989). Therefore, the soybean yield difference was the consequence of continuous grain sorghum and soybean production between 1980 and 2008 even though soil organic matter and nutrient levels of plots were all well above sufficiency levels (Ferguson et al., 2006) and in spite of the continuous soybean crop history being interrupted for $2 \mathrm{yr}$. Clearly continuous soybean production not only has a negative consequence on the succeeding soybean crop yield (Roder et al., 1089; Peterson and Varvel, 1989) but also has longer-term negative yield effects. This is an important consideration in countries where soybean is commonly grown without rotational crops.

\section{Soybean Nodule Numbers and Soil Nitrate-Nitrogen Concentration}

Neither manure, crop history nor inoculation had an effect on nodule numbers on soybean plants (Table 3). Averaged across years, manured plots had $8.9 \mathrm{mg} \mathrm{kg}^{-1}$ soil $\mathrm{NO}_{3}-\mathrm{N}$ concentration vs. $5.5 \mathrm{mg} \mathrm{kg}^{-1}$ for non-manured plots at the V4 growth stage, and $5.0 \mathrm{mg} \mathrm{kg}^{-1}$ vs. $3.0 \mathrm{mg} \mathrm{kg}^{-1}$ at the $\mathrm{R} 5$ growth stage. Soybean crop history increased the soil $\mathrm{NO}_{3}-\mathrm{N}$ concentration compared with grain sorghum crop history. However, the soil $\mathrm{NO}_{3}-\mathrm{N}$ concentration was higher and crop history difference greater in 2012 than $2011\left(9.7 \mathrm{mg} \mathrm{kg}^{-1}\right.$ vs. $6.8 \mathrm{mg} \mathrm{kg}^{-1}$ in 2012 , and 2.3 vs. $2.1 \mathrm{mg} \mathrm{kg}^{-1}$ in 2011). The higher soil $\mathrm{NO}_{3}-\mathrm{N}$ concentration in 2012 may have been due to greater soil mineralization resulting from higher temperatures (Table 2) as observed by MacDonald et al. (1995). Soybean crop history increased soil $\mathrm{NO}_{3}-\mathrm{N}$ concentration in the soil at both the V4 and $\mathrm{R} 5$ growth stages (Table 3 ). Soil $\mathrm{NO}_{3}-\mathrm{N}$ concentration has been shown to influence soybean nodule formation (Salvagiotti et al., 2008), but the range of soil $\mathrm{NO}_{3}-\mathrm{N}$ concentrations present in this study had no influence on soybean nodulation (data not presented).

Differences for the number of nodules among treatments at the V4 and R5 growth stages were greater in 2011 than in 2012, and increased between the V4 and R5 growth stages (Table 3). The difference in number of nodules was likely due to the cooler temperatures, higher rainfall (Table 2), and lower water stress in 2011 than in 2012 (Serraj et al., 1999; Purcell et al., 2004).

It was expected that the nodule number per soybean plant would be similar in plots with a soybean crop history and in inoculated plots with grain sorghum history, while noninoculated plots with grain sorghum history would have no or few nodules present (Larson, 2013; Schulz and Thelen, 2008; Elkins et al., 1976). However, no differences were found for the number of nodules between continuous grain sorghum and other crop systems. While this was unexpected, it has been previously documented in the literature (Larson, 2013; van Kessel

Table 3. Influence of crop history, year, manure and inoculation on soybean yield and number of nodules (no significant interaction effects were present).

\begin{tabular}{|c|c|c|c|}
\hline \multirow[b]{2}{*}{ Treatments } & \multirow[b]{2}{*}{ Grain yield } & \multicolumn{2}{|c|}{ Soybean nodules } \\
\hline & & V4 & R5 \\
\hline & $\mathrm{Mg} \mathrm{ha}-\mathrm{I}$ & no. & -1 \\
\hline \multicolumn{4}{|l|}{ Crop history } \\
\hline Soybean & 3.6 & 24.7 & 36.3 \\
\hline Sorghum & 4.1 & 24.4 & 34.8 \\
\hline Probability & $<0.01$ & 0.88 & 0.61 \\
\hline \multicolumn{4}{|l|}{ Year } \\
\hline 2011 & 4.0 & 28.0 & 38.0 \\
\hline 2012 & 3.8 & 21.5 & 33.1 \\
\hline Probability & 0.50 & 0.04 & 0.09 \\
\hline \multicolumn{4}{|l|}{ Manure } \\
\hline Manured & 3.9 & 25.6 & 36.2 \\
\hline Non-manured & 3.9 & 23.5 & 35.0 \\
\hline Probability & 0.98 & 0.25 & 0.67 \\
\hline \multicolumn{4}{|l|}{ Inoculation } \\
\hline Inoculated & 3.8 & 25.2 & 36.2 \\
\hline Non-inoculation & 3.9 & 24.0 & 35.0 \\
\hline Probability & 0.98 & 0.77 & 0.62 \\
\hline
\end{tabular}


and Hartley, 2000). The presence of nodules in non-inoculated soybean plots was likely due to movement of $B$. japonicum with soil from adjacent inoculated and/or well nodulated plots by wind and/or water, or from un-cleaned tillage equipment used in adjacent plots during the long-term study (Lowther and Patrick (1993).

\section{CONCLUSION}

Soybean grain yield was $0.5 \mathrm{Mg} \mathrm{ha}^{-1}$ greater on plots with grain sorghum crop history than soybean history, even though this history was broken by 2 or $3 \mathrm{yr}$ of grain sorghum production and no significant differences in soil organic matter or nutrient levels were found. Continuous production of soybean in the same field produces lower yields, due to lack of short-term crop rotation yield enhancement and long-term crop history effects. This result is logical, but this long-term effect has not been previously reported. Surprisingly, soybean planted into plots after continuous grain sorghum production for more than $30 \mathrm{yr}$ had similar number of nodules to plots with soybean history and/or plots inoculated with B. japonicum at planting. This is likely due to movement over time of B. japonicum among adjacent plots by wind and/or water erosion, and/or contaminated tillage equipment, but also confirms other reports of nodule formation in fields without application of inoculant. Although the exact reason for long-term soybean crop history on yield is unclear, continuous soybean production should be avoided if possible and further study on B. japonicum inoculation of fields without soybean history is merited.

\section{REFERENCES}

Abendroth, L.J., and R.W. Elmore. 2006. Soybean inoculation: Applying the facts to your field. NebGuide G1622. Univ. of Nebraska Coop. Ext. Serv., Lincoln.

Albareda, M., D.N. Rodríguez-Navarro, and F.J. Temprano. 2009. Soybean inoculation: Dose, $\mathrm{N}$ fertilizer supplementation and rhizobia persistence. Field Crops Res. 113:352-356. doi:10.1016/j.fcr.2009.05.013

Bagayoko, M., S.C. Mason, and R.J. Sabata. 1992. Residual effects of cropping systems on soil nitrogen and grain sorghum yields. Agron. J. 84:862-868. doi:10.2134/agronj1992.00021962008400050019x

Combs, S.M., J.L. Denning, and K.D. Frank. 1998. Sulfate-sulfur. In: J.R. Brown, editor, Recommended chemical soil test procedures for the north central region. North Central Publ. no. 221 (Revised). Univ. of Missouri Agric. Exp. Stn., Columbia. p. 35-40.

De Bruin, J.L., P. Pedersen, S.P. Conley, J.M. Gaska, S.L. Naeve, J.E. Kurle et al. 2010. Probability of yield response to inoculants in fields with a history of soybean. Crop Sci. 50:265-272. doi:10.2135/cropsci2009.04.0185

Elkins, D.M., G. Hamilton, C.K.Y. Chan, M.A. Briskovich, and J.W. Vandeventer. 1976. Effect of cropping history on soybean growth and nodulation and soil rhizobia. Agron. J. 68:513-517. doi:10.2134/agronj1976.000 $21962006800030019 \mathrm{x}$

Ferguson, R.B., C.A. Shapiro, A.R. Dobermann, and C.S. Wortmann. 2006. Fertilizer recommendations for soybean. NebGuide G859, Univ. of Nebraska Coop. Ext. Serv., Lincoln.

Furseth, B.J., S.P. Conley, and J. Ané. 2012. Soybean response to soil rhizobia and seed-applied inoculants in Wisconsin. Crop Sci. 52:339-344. doi:10.2135/cropsci2011.01.0041

Ganeshamurthy, A.N., and K.S. Reddy. 2000. Effect of integrated use of farmyard manure and sulphur in a soybean and wheat cropping system on nodulation, dry matter production and chlorophyll content of soybean on swell shrink soils in Central India. J. Agron. Crop Sci. 185:91-97. doi:10.1046/j.1439-037x.2000.00403.x

Gelderman, R.H., and D. Beegle. 1998. $\mathrm{NO}_{3}-\mathrm{N}$ Nitrogen. Recommended chemical soil test procedures for the north central region. Missouri Agric. Exp. Stn, Columbia.

Javaid, A., and N. Mahmood. 2010. Growth, nodulation and yield response of soybean to biofertilizers and organic manures. Pak. J. Bot. 42:863-871.
Johnson, H.S., and D.J. Hume. 1972. Effects of nitrogen sources and organic matter on nitrogen fixation and yield of soybean. Can. J. Plant Sci. 52:991-006. doi:10.4141/cjps72-170

Kaye, N.M., S.C. Mason, T.D. Galusha, and M. Mamo. 2007. Nodulating and non-nodulating soybean rotation influence on soil nitrate-nitrogen and water, and sorghum yield. Agron. J. 99:599-606. doi:10.2134/ agronj2005.0290

Larson, K. 2013. Evaluation of soybean inoculant products and techniques to address soybean nodulation problems in Kansas. M.S. thesis. Kansas State Univ., Manhattan.

Larson, J.L., and E. Siemann. 1998. Legumes may be symbiont-limited during old-field succession. Am. Midl. Nat. 140:90-95. doi:10.1674/0003-0031(1998)140[0090:LMBSLD]2.0.CO;2

Lowther, W.L., and H.N. Patrick. 1993. Spread of Rhizobium and Bradyrhizobium in soil. Soil Biol. Biochem. 25:607-612. doi:10.1016/0038-0717(93)90200-U

MacDonald, N.W., D.R. Zak, and K.S. Pregitzer. 1995. Temperature effects on kinetics of microbial respiration and net nitrogen and sulfur mineralization. Soil Sci. Soc. Am. J. 59:233-240. doi:10.2136/ sssaj1995.03615995005900010036x

Meriles, J.M., S. Vargas Gil, C. Conforto, G. Figoni, E. Lovera, G.J. March, and C.A. Guzmán. 2009. Soil microbial community under different soybean cropping systems: Characterization of microbial population dynamics, soil microbial activity, microbial biomass, and fatty acid profiles. Soil Tillage Res. 103:271-281. doi:10.1016/j.still.2008.10.008

Pedersen, P. 2009. Soybean growth and development. PM 1945. Iowa State Univ. Ext., Ames.

Peterson, T.A., and G.E. Varvel. 1989. Crop yield as affected by rotation and nitrogen rate. I. Soybean. Agron. J. 81:727-731. doi:10.2134/agronj1989. $00021962008100050005 x$

Purcell, L.C., R. Serraj, T.R. Sinclair, and A. De. 2004. Soybean $N_{2}$ fixation estimates, ureide concentration, and yield response to drought. Crop Sci. 44:484-492. doi:10.2135/cropsci2004.4840

Roder, W., S.C. Mason, M.D. Clegg, J.W. Doran, and K.R. Kniep. 1988. Plant and microbial responses to sorghum-soybean cropping systems and fertility management. Soil Sci. Soc. Am. J. 52:1337-1342. doi:10.2136/ sssaj1988.03615995005200050024x

Roder, W., S.C. Mason, M.D. Clegg, and K.R. Kniep. 1989. Yield-soil water relationships in sorghum-soybean cropping systems with different fertilizer regimes. Agron. J. 81:470-475. doi:10.2134/agronj1989.000219620 08100030015x

Ruiz Diaz, D.A., P. Pedersen, and J.E. Sawyer. 2009. Soybean response to inoculation and nitrogen application following long-term grass pasture. Crop Sci. 49:1058-1062. doi:10.2135/cropsci2008.08.0510

Salado-Navarro, L.R., and T.R. Sinclair. 2009. Crop rotations in Argentina: Analysis of water balance and yield using crop models. Agric. Syst. 102:11-16. doi:10.1016/j.agsy.2009.06.004

Salvagiotti, F., K.G. Cassman, J.E. Specht, D.T. Walters, A. Weiss, and A.R. Dobermann. 2008. Nitrogen uptake, fixation and response to fertilizer N in soybean: A review. Field Crops Res. 108:1-13. doi:10.1016/j. fcr.2008.03.001

SAS Institute. 2014. SAS/STAT 9.3 users guide. SAS Inst., Cary, NC.

Schulz, T.J., and K.D. Thelen. 2008. Soybean seed inoculant and fungicidal seed treatment effects on soybean. Crop Sci. 48:1975-1983. doi:10.2135/ cropsci2008.02.0108

Serraj, R., T.R. Sinclair, and L.C. Purcell. 1999. Symbiotic $\mathrm{N}_{2}$ fixation response to drought. J. Exp. Bot. 331:143-155.

Tagoe, S.O., T. Horiuchi, and T. Matsui. 2008. Effects of carbonized and dried chicken manures on the growth, yield and $\mathrm{N}$ content of soybean. Plant Soil 306:211-220. doi:10.1007/s11104-008-9573-9

van Kessel, C., and C. Hartley. 2000. Agricultural management of grain legumes: Has it led to increased nitrogen fixation. Field Crops Res. 65:165-181. doi:10.1016/S0378-4290(99)00085-4

Wortman, S.E., T.D. Galusha, S.C. Mason, and C.A. Francis. 2012. Soil fertility and crop yields in long-term organic and conventional cropping systems in Eastern Nebraska. Renew. Agric. Food Syst. 27:200-216. doi:10.1017/S1742170511000317

Wortmann, C.S., and C.A. Shapiro. 2012. Calculating the value of manure for crop production. NebGuide G1519. Univ. of Nebraska Coop. Ext. Serv., Lincoln. 